PRIVATIZATION AND ENTREPRENEURSHIP IN POST-SOCIALIST COUNTRIES 


\section{Privatization and Entrepreneurship in Post-Socialist Countries}

\section{Economy, Law and Society}

Edited by

\section{Bruno Dallago}

Associate Professor of Economic Policy

and Comparative Economic Systems

University of Trento, Italy

\section{Gianmaria Ajani}

Professor of Comparative Law

University of Trento, Italy

and

\section{Bruno Grancelli}

Lecturer in the Department of Social Policy

University of Trento, Italy

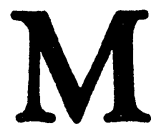

St. Martin's Press 
(C) Bruno Dallago, Gianmaria Ajani and Bruno Grancelli 1992

Softcover reprint of the hardcover 1st edition 1992

All rights reserved. No reproduction, copy or transmission of this publication may be made without written permission.

No paragraph of this publication may be reproduced, copied or transmitted save with written permission or in accordance with the provisions of the Copyright, Designs and Patents Act 1988, or under the terms of any licence permitting limited copying issued by the Copyright Licensing Agency, 90 Tottenham Court Road, London WIP 9HE.

Any person who does any unauthorised act in relation to this publication may be liable to criminal prosecution and civil claims for damages.

First published in Great Britain 1992 by

MACMILLAN PRESS LTD

Houndmills, Basingstoke, Hampshire RG21 2XS

and London

Companies and representatives

throughout the world

A catalogue record for this book is available from the British Library.

ISBN 978-1-349-12395-7 ISBN 978-1-349-12393-3 (eBook)

DOI 10.1007/978-1-349-12393-3
$\begin{array}{lllllllll}11 & 10 & 9 & 8 & 7 & 6 & 5 & 4 & 3\end{array}$
$\begin{array}{llllllllll}04 & 03 & 02 & 01 & 00 & 99 & 98 & 97 & 96 & 95\end{array}$

First published in the United States of America 1992 by

Scholarly and Reference Division,

ST. MARTIN'S PRESS, INC.,

175 Fifth Avenue,

New York, N.Y. 10010

ISBN 978-0-312-08100-3

Library of Congress Cataloging-in-Publication Data

Privatization and entrepreneurship in post-socialist countries :

economy, law, and society / edited by Bruno Dallago, Gianmaria

Ajani, and Bruno Grancelli.

p. $\mathrm{cm}$.

ISBN 978-0-312-08100-3

1. Privatization-Europe, Eastern. 2. Privatization-Law and legislation-Europe, Eastern. 3. Privatization-Central Europe.

4. Privatization-Law and legislation-Central Europe.

5. Entrepreneurship-Europe, Eastern. 6. Entrepreneurship-Central

Europe. 7. Post-communism-Europe, Eastern. 8. Post-communism-

-Central Europe. I. Dallago, Bruno, 1950- . II. Ajani ,

Gianmaria. III. Grancelli, Bruno, 1943- .

HD4140.7.P75 1992

$338.947-\mathrm{dc} 20$ 


\section{Contents}

page

About the authors vii

Foreword $\quad x i$

Introduction 1

Gianmaria Ajani, Bruno Dallago, Bruno Grancelli

Part One: The autonomous sector, entrepreneurship and transition

1 The autonomous sector in a society of shortage Horst Brezinski

2 Perestroika, the autonomous sector and the transition from the 'contra-system' to a civil society?

Robert Sharlet

3 Property relations in the period of transition

Marton Tardos

4 Issues in state and private sector relations in the Soviet economy

Anthony Jones

5 Organizational innovation and entrepreneurial formation. Some comparative remarks Bruno Grancelli

6 From underground to legitimacy: The normative dilemmas of post-communist marketization Maria Łos

7 Seeking legal forms for the autonomous sector Victor P. Mozolin 
Part Two: Economic, legal and social problems of ownership transformation

8 The reality and potential of autonomous entrepreneurship

Teréz Laky

9 Transformation of a centrally-directed economy: Ownership and privatization in Hungary during 1990

Paul Marer

10 The role of law in autonomization of the USSR economy

John Hazard

11 New economic forms, Soviet labour law and the trade unions

Ger Van den Berg

12 The entrepreneurial spirit and Soviet medicine David Powell

Part Three: The cooperative movement in the Soviet Union

13 The role of new cooperatives in the Soviet economy

Domenico M. Nuti

14 Soviet cooperatives and the labour market

275

Silvana Malle

15 Entrepreneurship: Some legal and social problems

307 Louise Shelley

16 The role of the non-socialized sector in perestroika: Present state and prospects

Svetlana Glinkina

17 On the efficiency of Soviet cooperatives: A critical appraisal

Ruud Knaak 


\section{About the authors}

Gianmaria Ajani, Professor of Comparative Law, Director of the Department of Legal Sciences, Faculty of Law, University of Trento, Italy. He has published two books on the sources of law and on property rights in the Soviet Union and Central and Eastern Europe.

Horst Brezinski is Senior Lecturer at the University of Paderborn, Department of Economics and Business Administration, Germany. He has published articles on COMECON and the second economy in the Soviet Union and Eastern Europe. His book The Shadow Economy in East, West and South: a Comparative View is forthcoming. His main research interests are comparative economic systems and international economic relations.

Bruno Dallago is Associate Professor of Economic Policy and Comparative Economic Systems at the University of Trento, Italy, and secretary of the European Association for Comparative Economic Studies. He is author of The Irregular Economy (Dartmouth, 1990) and editor of The Unofficial Economy with S. Alessandrini (Gower, 1987), Economic Planning and Transition with J. Kovàcs (Dartmouth, 1990) and Convergence and System Change with $\mathrm{H}$. Brezinski and W. Andreff (Dartmouth, 1991).

Svetlana Glinkina is Professor of Economics at the Institute of International Economic and Political Studies in Moscow, USSR. She is author of the monograph Cooperatives in Socialist Countries and several articles published in the journals Voprosy Ekonomiki, Sotsiologicheskie Issledovania, Izvestia Akademii Nauk. Seria Ekonomicheskaya.

Bruno Grancelli is a lecturer at the University of Trento, Department of Social Policy, Italy. His publications include Soviet Management and Labour Relations (Allen and Unwin, Boston, 1988)

John Hazard, Nash Professor Emeritus of Law, Columbia University, New York. Author of literally hundreds of articles and many books on Soviet and socialist law. He has also published the celebrated Communists and Their Law: a Search for the Common Core of the Legal Systems of the Marxian Socialist States (1969). 
Anthony Jones is Associate Professor of Sociology at Northeastern University and fellow of the Russian Research Center, Harvard University. His most recent publications include: Co-ops: The Rebirth of Entrepreneurship in the Soviet Union (with W. Moskoff) and Professions and the State (ed.).

Ruud Knaak is Associate Professor of Economics, Department of Micro-economics, University of Amsterdam. He is a specialist on Eastern European economics and the author of Contradictions in Socialist Planning as well as numerous articles and chapters on various aspects of the reform movement in Eastern Europe and China.

Teréz Laky is Head of Department of the Research Institute of Labour, Hungarian Ministry of Labour Affairs, Budapest and Associate Professor at Budapest University of Economics, Department of Sociology.

Maria Łos is Professor of Criminology at the University of Ottawa, Canada, and Adjunct Professor at the Institute of Soviet and East European Studies, Carleton University. Her publications include The Second Economy in Marxist States (ed.), Communist Ideology, Law and Crime and Multi-Dimensional Sociology (co-author).

Silvana Malle is Professor of Comparative Economic Systems and director of the Centre of East West Studies and European Integration at the University of Verona, Italy. Her major works are: The Economic Organization of War Communism, 1918-1921 (Cambridge University Press, 1985) and Employment Planning in the Soviet Union. Continuity and Change (Macmillan, 1990).

Paul Marer is Professor of International Business at the Indiana University School of Business. In 1990 he was appointed by President Bush as a trustee of the Hungarian-American Enterprise Fund, which sets policy on the allocation of the 60-million-dollar grant given by the United States to Hungary for the promotion of private enterprise.

Victor P. Mozolin, Professor of Civil Law, Senior Research member of the Institute of State and Law of the USSR Academy of Sciences. A specialist on the law of ownership and contracts, he has 
published essays in English in the series 'Contract Law in the USSR and the United States'.

Domenico M. Nuti works at the Commission of the European Communities and is Professor at the University of Siena, Italy, having previously worked at the European University Institute, Florence. He has authored various studies on Eastern European economies.

David Powell is a fellow of the Russian Research Center at Harvard University. His recent publications include the book Soviet Social Problem (edited with T.A. Jones) (Blackwell, 1990).

Robert Sharlet, Professor of Political Science, Union College Schenectady, New York, USA, specializes in Soviet and East European politics and law. He has published five books and is just completing a sixth: Soviet Constitutional Crisis: Politics and Law in the USSR (M. E. Sharpe Publishers, forthcoming).

Louise Shelley is Chair and Professor in the Department of Justice, Law and Society and in the School of International Service, The American University Washington. She is author of the books Crime and Modernization, Lawyers in Soviet Worklife (Rutgers Univ. Press, New Brunswick, N.J.) and Policing the Soviet Society (forthcoming).

Màrton Tardos has been a member of the Hungarian Parliament since 1990, and was previously research fellow and head of department at the Foreign Trade Institute of Budapest and at the Institute of Economics.

Ger Van den Berg is Senior Researcher in the Documentation Office for East European Law, University of Leyden, Holland. He is the author of many books and articles on the Soviet legal system. 


\section{Foreword}

It was our desire to clarify the issues outlined in the introduction to this book that prompted us to organize an international conference (at Trento, Italy, 8-11 April 1990), the aim being to compare the experiences of the various countries of the East and draw on the knowledge of outstanding scholars from these countries and the West.

The conference took place at a particularly appropriate moment. The political situation internal to these countries had by then become sufficiently clear, with the formation of new democratic governments and the accumulation by others of their first, precious experience. At the time of the conference, the outcomes of economic options and legal evolution in these countries were highly uncertain, as they are still today, with the partial exception of Poland. Thanks to our fortunate timing, the conference turned into an invaluable forum for the interdisciplinary analysis and comparison of such themes of outstanding immediacy and relevance as privatization and entrepreneurship in the countries of ex-real socialism.

However, although this book has grown out of the conference, it seeks to be more than just a collection of papers. The contributors have incorporated into their essays the assessments made of their papers at the conference and points raised in the ensuing debate.

Bob Sharlet, Louise Shelley and John Hazard remind us that the Soviet state, far from acting as the arbiter of market process, is still an instrument manipulated by the bureaucracy either to obstruct privatization or to encourage it in certain sectors, according to considerations of corporative opportunism. Viktor Mozolin guides us through the system of legal rules that should govern transition, while Ger van den Berg explores the relation between entrepreneurship and work relationships. Louise Shelley, again, shows that cooperatives are, in certain respects, subject to increasing regulation at the sublegal level, while in others they are trapped in a vacuum of legal, economic and financial structures which force them to resort to illegalities in their search for resources.

David Powell, in his study of medical cooperatives in the USSR, demonstrates that the underlying causes of the spread of private medicine lie with the real functioning of central planning and with bureaucratic performance standards. Tony Jones broadens the 
xii

analysis to examine the wider range of the forces that have favoured the institutionalization of entrepreneurship in the Soviet Union. He explains why there is increasing collusion, in a variant of a black economy, between state and private sectors. Bruno Grancelli describes some organizational and socio-cultural settings which have helped new (and old) forms of entrepreneurship to emerge in the terminal stage of the command economy. Maria Łos, in her comparative study of underground entrepreneuship in ten socialist and post-socialist countries, provides a wealth of information on the corrupt and ritualistic relations between economic agents and the state bureaucracy.

Horst Brezinski outlines a theoretical scheme for interpreting the role of the autonomous (non-state) sector in a traditional shortage economy. Màrton Tardos examines the problem of property relationships in the transition from the Soviet-type system to a market economy. Terez Laky's contribution analyses the development of the autonomous sector in Hungary over the past fifty years, paying particular attention to the repeated attempts at reform of the 1980s. Paul Marer sets out the chief problems faced by Hungary in its privatization programme and transition to a market economy. Svetlana P. Glinkina takes a close look at the role of the nonsocialized sector - in particular new cooperatives - in the Soviet Union of perestroika, while Domenico Mario Nuti analyses the vicissitudes of the law on cooperatives in the Soviet Union, highlighting its contradictions. Silvana Malle gives a detailed description of the new Soviet cooperatives while stressing their problematic role in today's Soviet Union and their relations with the state sector. Ruud Knaak, after discussing the political and economic environment of the new Soviet cooperatives, addresses the important issue of efficiency.

The Conference's opening round table and its closing discussion were enriched by contributions from W. Andreff, D. Barry, J. Beksiak, A. Bergson, J. Berliner, R. Buxbaum, G. Crespi Reghizzi, F. Feldbrugge, P. Hanson, T. Horvàth, H. Izdebski, T. Jezek, K. Jowitt, A. Klishin, D. Loeber, P. Maggs, S. Manezhev, B. Ruble, B. Rudden, W.B. Simons, D. Stark, V. Valli, K. Waedekin, Jinglian $\mathrm{Wu}, \mathrm{Z}$. Zile.

The written contributions to the Conference were of such interest that it was decided to publish two separate books. The present volume contains essays concentrating specifically on processes of privatization in the ex-socialist countries. The other volume, 
published in Italian by the Banca di Trento e Bolzano, Trento, as a book in the series edited by the journal Economia e Banca, contains a selection of papers giving a general overview of the current situation in the East European countries and China.

The organization of the conference and the publication of the present book could not have been possible without the generous help of various institutions and the unstinting work of a number of people. Apart from the Departments of Law, Economics and Social Policy, and the Rector of Trento University, we wish to thank the Provincia Autonoma di Trento and its President, Mario Malossini, the Consiglio Nazionale delle Ricerche, the Banca di Trento e Bolzano and the Istituto Trentino di Cultura, and also UNESCO for supporting the Conference.

Invaluable for the organization and successful outcome of the Conference was the work of Edith J. Kismarjay, Federica Silvestri, Brigitte Branche, and that of the administrative and secretarial staff of the Departments listed above. Finally, Edith J. Kismarjay helped with the editing of the present volume, Adrian Belton carefully revised the English texts, and Cooperativa Prisma prepared the camera-ready copy. 